\title{
The development of the aviation fuel market in Poland and changes in civil passenger traffic
}

ABSTRACT: The development of air transport affects elements of the aviation fuel market. In recent years an increase in both the number of passengers and the number of passenger operations has been observed. This phenomenon also concerns passengers and the number of operations served by Polish airports which translates into more and more fuel consumption in Poland.

The authors of the study tried to approximate the characteristics of aviation fuels used in various types of aircrafts. The most important of them, from the perspective of the Polish aviation sector, include Jet. This type of fuel plays a key role in civil aviation.

In the article, the enterprises operating in the analyzed sector were also reviewed. The empirical part of the article is devoted, in turn, to the analysis of changes in air passenger transport in Poland and changes in Jet fuel prices on the Polish fuel markets. The conducted research shows that the dynamics of changes in the number of passengers, as well as the number of passenger operations at Polish airports were characterized by an upward trend, and the increase in the number of passengers was driven not only by a larger number of available flights, but also by such factors as: increasing the capacity of aircraft and increasing the fill rate for seats.

The authors have also attempted to examine the strength of dependence between the number of passengers deciding to use Polish airports and Jet fuel prices, which in recent years have undergone significant fluctuations.

\footnotetext{
${ }^{1}$ Department of Management, AGH University of Science and Technology, Kraków, ORCID ID: 0000-0001-68822690; e-mail: jmuweis@zarz.agh.edu.pl

2 Department of Management, AGH University of Science and Technology, Kraków, ORCID ID: 0000-0002-22564654; e-mail: blamasz@zarz.agh.edu.pl
} 
For this purpose, the value of Pearson's linear correlation coefficient was used and the analyzed period covered the years 2011-2017. The data on passenger traffic used in the study came mainly from periodic reports prepared by the Civil Aviation Office (ULC).

KEYWORDS: aviation fuel market, aviation fuel prices, air passenger transport

\section{Introduction}

The economic situation and the changes taking place in air transport are issues that undoubtedly have a significant impact on the volume of the demand for petroleum products. One of the segments of transport referred to in English as general aviation - GA (general aviation, including air traffic excluding scheduled flights - airlines and the army) is beginning to play an increasingly important role in this aspect. There are some organizations important for the aviation fuel market. One of them, The International Civil Aviation Organization, acts as a specialized agency of the United Nations. It fosters, among others: planning and development of international air transport or principles and techniques of international air navigation. According to reports published by the International Council of Airports (ACI), passenger traffic has been increasing in the last 3 years (2015-2017). According to initial summaries, only in 2017, there was an increase in passenger traffic, which was $6.6 \%$ compared to 2016 . The latest forecasts also indicate that a further increase in demand for air transport, which will mainly be driven by developing countries and located in Asia and the Pacific, is inevitable. It is estimated that in the period from 2016 to 2040, airports from this part of the world will increase their share in global passenger traffic from 45 to $62 \%$ (Rynek Lotniczy 2018).

Changes in the air passenger traffic in the world and also in Poland translate into the fuel market, in particular Jet A-1. The demand for fuels is also growing because of the increased demand for aviation fuels due to the dislocation of allied troops (Bernaciak 2017).

In the work, the types of aviation fuels were analyzed, with special attention to Jet fuel. This is the most important fuel for civil aviation. In Poland, the second type of aviation fuel - Avgas is also used. However, this fuel plays a marginal role in the total passenger transport of Poland, as it is used in small airplanes with piston engines. On the other hand, airplanes used in passenger transport have turbojet engines requiring Jet fuel. In addition, the structure of the aviation fuel market in Poland was analyzed, including the most important entities. The supply and prices of the fuels in question are correlated with the demand determined by the increase in passenger traffic. After analyzing the changes in passenger air traffic in Poland in 2010-2017, the number of passengers at individual airports with Jet fuel prices was compared. Pearson's correlation coefficient in 2011-2017 was used to examine the strength of this relationship. 


\section{Types of aviation fuels used in aircrafts}

Aviation fuels are fuels used to drive aircraft engines. There are various divisions of fuels of this type. This part of the paper discusses classifications that take aspects such as the chemical composition of fuels and their various applications into account. Due to the chemical composition, the basic range of fuels in the aircraft spark-ignition engines, includes three gasoline grades with different contents of lead tetraethyl and properties differentiated in trade in the appropriate color:

$\downarrow$ low lead (Avgas 80) in red,

$\checkmark$ average lead 100 LL (Avgas 100LL) in blue,

$\checkmark$ high lead 100 (Avgas 100) in green (Pągowski 2009, p. 119).

Another classification used is the division due to the use of fuels in specific engine types. The engines themselves are divided into two basic groups: piston (with spark or self-ignition) and turbine (jet, helicopter, propeller and rocket). The three gasoline grades mentioned in the first classification are used in the piston engines. However, aviation oils are used in each of the turbine engines. Table 1 lists the other types of aviation fuels used in particular types of engines.

TABLE 1. Division of aviation fuels due to the type of engine in which they are used

TABELA 1. Podział paliw lotniczych ze względu typ silnika, w którym są stosowane

\begin{tabular}{|l|c|c|c|c|c|c|}
\hline \multirow{2}{*}{ Fuel type } & \multicolumn{7}{|c|}{ Engine type } \\
\cline { 2 - 7 } & Jet & helicopter & propeller & rocket & $\begin{array}{c}\text { piston with spark or } \\
\text { self-ignition }\end{array}$ & $\begin{array}{c}\text { piston with } \\
\text { self-ignition }\end{array}$ \\
\hline Heavy gasoline & $\mathrm{x}$ & & & & $\mathrm{x}$ & \\
\hline Wide fractional fuels & $\mathrm{x}$ & $\mathrm{x}$ & $\mathrm{X}$ & & & $\mathrm{x}$ \\
\hline Fuel oils & $\mathrm{x}$ & & & $\mathrm{x}$ & & \\
\hline Aviation oil & $\mathrm{x}$ & $\mathrm{x}$ & $\mathrm{X}$ & $\mathrm{x}$ & & \\
\hline
\end{tabular}

Source: own study based on: (Pągowski 2009, pp. 120-121; IATA 2015).

In addition to the division introduced, it is worth noting that in turbine jet engines, fuels are divided into used fuels:

$\downarrow$ in civil aviation according to IATA (The International Air Transport Association): Jet A-1, Jet A, Jet B;

$\checkmark$ in military aviation according to NATO codes and Stanag 3747 accordingly: F-35, F-34 (JP8), F 40, F 44 (JP-5) (Pągowski 2009, p. 121).

One of the most popular types of fuel nowadays is fuel for turbojet engines and commercial air transport and military aviation are mainly based on it. This type of fuel is named Jet or Jet A1. In turn, Avgas fuel is used in piston engines. However, in passenger traffic, Jet engine aircrafts 
are the most popular. Therefore, before approaching the structure of the Polish aviation market, it is worth looking at the shape of the Jet fuel market in recent years.

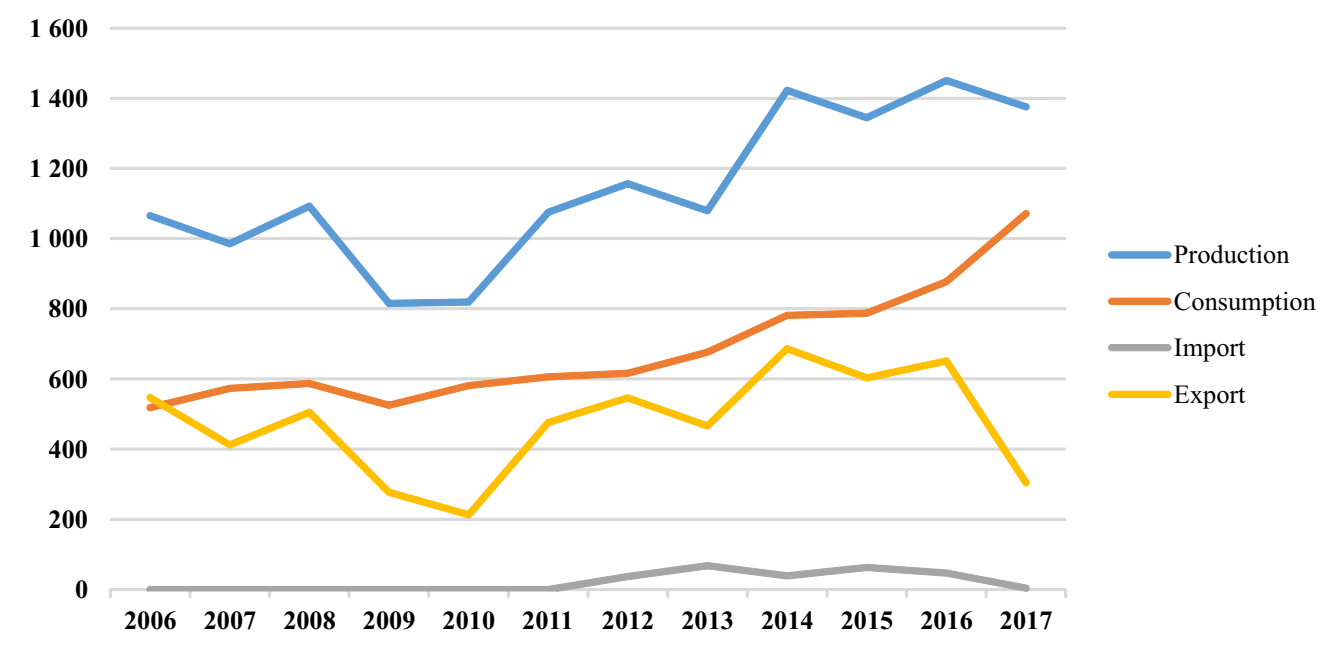

Fig. 1. Volume of Jet fuel consumption, production, import and export (in thousands of $\mathrm{m}^{3}$ ) in Poland in 2006-2017 Source: own study based on data from The Polish Oil Industry and Trade Organization (POPiHN)

Rys. 1. Wielkość konsumpcji, produkcji, importu i eksportu paliwa Jet (w tys. $\mathrm{m}^{3}$ ) w Polsce w latach 2006-2017

Jet air fuel is becoming more and more popular on the Polish aviation market as evidenced by its growing consumption in recent years (see Figure 1). According to the reports of The Polish Oil Industry and Trade Organization a particularly intense increase in Jet consumption was recorded in 2017, when it amounted to over 1 million $\mathrm{m}^{3}$ (year-on-year increase exceeding 20\%). The upward trend for fuel consumption has been consistently stable since 2010. However, the situation for the Jet production is slightly different, which in recent years has oscillated around 1.4 million $\mathrm{m}^{3}$ without showing major changes. It is also worth noting the significant decrease in the level of Jet fuel export in 2017 (over 50\% in relation to 2016). This phenomenon suggests that the domestic production of this fuel (with a marginal level of its imports) is, for the most part, spent on domestic consumption (about $78 \%$ in 2017).

\section{Structure of the aviation fuel market}

The aim of this part of the study was to approximate the structure of the aviation fuel market and to discuss the main entities responsible for the functioning of the aviation market in Poland. 
The structure of the aviation fuel market, including entities operating on it, was presented using the scheme, created in the form of Figure 2.

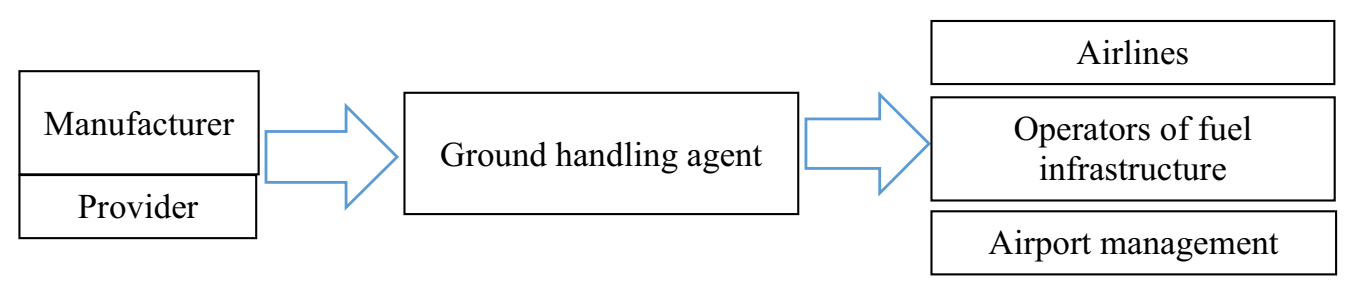

Fig. 2. Entities operating on the aviation fuel market

Source: own study

Rys. 2. Podmioty działające na rynku paliw lotniczych

The main entities are fuel producers and suppliers. The entity that is the link between them and the other entities is the ground handling agent. Then the fuel eventually reaches the operators of fuel infrastructure, specific airlines, and its purchase is coordinated by the airport management.

The manufacturer and provider have the key role among the entities operating on the fuel market. The ground handling agent is an authorized enterprise that carries out economic activity at public airports in the field of the ground handling of aircraft, cargo and passengers. The most significant companies producing aviation fuels in Poland are analyzed below. There are two leading companies which produce aviation fuel in Poland. One of them is a company operating on the basis of a joint venture of Grupa LOTOS: LOTOS - Air BP Polska. They are the leading Polish producer of Jet A-1 fuel. The company is part of the air division of Air BP - the British Petroleum group, which is the largest supplier of aviation fuels in the world.

PKN Orlen is the second company with a key position on the aviation fuel market in Poland. The company sells JET A-1 and AVGAS 100 LL aviation fuels. This entity has been a significant supplier of this type of fuel also on the Czech market since April 2017. It is worth noting that PKN ORLEN sells aviation fuel from Unipetrol (a company owned by PKN ORLEN), therefore from refineries located in the Czech Republic (at the production plant in Kralupy, and from mid-2018 also in Litvinov). This is evidenced that Unipetrol sold 100 million liters of aviation fuel at Václav Havel Airport Prague according to data from February 20, 2018. Thus, it became the second largest supplier of fuels at the largest Czech airport with $20 \%$ participation (Walków 2018).

ORLEN AVIATION (operating in the PKN ORLEN group since 1997), currently operates under the name PETROLOT. It is the part of PKN ORLEN. The position of the company has become even more significant in the aviation fuels sector since January 1, 2014, ever since PKN ORLEN provides the supply of aviation fuel at airports, resulting from PETROLOT contracts with the Airports and Carriers. However PETROLOT currently acts as a ground handling agent and deals with the organization and activities related to fuel refueling and storage at Airports. 
PETROLOT invests in modern cisterns that guarantee greater efficiency of operations carried out at airports. This enterprise is a provider and the ground handing agent.

WARTER aviation is another company that is an aviation fuel supplier operating on the Polish market. It deals with the sale, distribution and promotion of the highest quality aviation gasoline offered by Water aviation the Płock Research and Development Center OBR S.A. WARTER aviation operates both on the Polish market and on foreign markets. The most popular type of gasoline sold by the company is Avgas 100LL.

An example of an enterprise that is important for fuel infrastructure in Poland is Flow Technics Ltd. having a container refueling station - KSTS 200/10. In addition, its offer includes aggregates for refueling aircraft for airport tanks and dispensers. The company also offers metering stations for aviation fuel additives, mobile devices for metrological control, filtration kits for aviation fuel.

Apart from the entities regulating the operation of the aviation sector, the aviation fuel infrastructure remains an important aspect, which includes: tanks, pipelines, fuel installations and distributors. The fuel infrastructure of aviation fuels should comply with European Union regulations regarding equipment used for ground handling. Storage tanks should be properly secured and controlled for the quality of the stored fuel. The equipment used in the aviation fuel station is for example: a microfilter, a water separator for fueling jet engines, a control filter, and a metering device. The PN-EN 12312-5 + A1 standard is an example of regulation of an aviation fuel station.

\section{Analysis of changes in passenger traffic in Poland in 2010-2017}

This part of the study analyzes the dynamics of changes taking place in passenger traffic in Poland in the last 8 years (2010-2017). Reviewing the reports illustrating the Polish aviation market, many indicators can be found that describe the current situation in this trade and compare it with previous periods. The authors of the study focused on two basic measures, which in their opinion best reflect the dynamics of changes in the Polish aviation sector - the number of passengers, the number of operations carried out at individual airports.

Passengers should be understood as persons transported by airplanes of Polish entities holding a license for air transport, in all types of flights (scheduled, additional and rented - charter flights), on domestic and foreign lines and outside these lines, as well as on roundabouts trips over the airport (GUS 2018).

In the analysis, the transport of both passengers using domestic and international transport were taken into account. Passengers transported by special purpose aviation aircraft (aeroclubs, sanitary aviation, agro-aviation) were not taken into account. Next, the number of flight opera- 
tions (of passengers) should be understood as the number of flights that took place in a given year. This value is the quotient of the number of passengers and the number of operations. Data regarding these three values (in relation to particular years) is included in Table 2.

TABLE 2. Total number of passengers and flight operations and the average number of passengers per flight in Poland in 2010-2017

TABELA 2. Całkowita liczba pasażerów i operacji lotniczych oraz średnia liczba pasażerów przypadających na jeden lot w Polsce w latach 2010-2017

\begin{tabular}{|c|c|c|c|}
\hline Year & Number of passengers & Number of operations & $\begin{array}{c}\text { Average number } \\
\text { of passengers per 1 flight }\end{array}$ \\
\hline 2010 & $20,466,876$ & 240,691 & 85 \\
\hline 2011 & $21,711,135$ & 246,679 & 88 \\
\hline 2012 & $24,435,557$ & 276,696 & 88 \\
\hline 2013 & $24,982,623$ & 263,028 & 95 \\
\hline 2014 & $27,077,970$ & 268,924 & 101 \\
\hline 2015 & $30,403,106$ & 283,294 & 107 \\
\hline 2016 & $34,006,715$ & 309,663 & 110 \\
\hline 2017 & $39,972,294$ & 341,199 & 117 \\
\hline
\end{tabular}

Source: own study.

As it can be seen from the above comparison, all the parameters included in the analyses showed an upward trend in 2010-2017. The largest percentage increase was recorded in the number of passengers, which increased by almost $100 \%$ in comparison to 2010 , and according to the latest available statistics is nearly 40 million (Table 2 ). These increases were particularly dynamic in 2012, as well as in 2015-2017, when they exceeded 10\% year-on-year. In the case of the number of operations, the upward trend was stopped only in 2013 and was caused by the increase in the average size of aircraft servicing the Polish market in this period, as well as the increase in the load factor. The load-factor ratio is calculated as the ratio of the number of passengers and the number of available seats. It can be counted for individual cruises, routes or the entire carrier's grid (Sipiński 2014; ULC 2013).

In the period under consideration, there is also a clear increase in the number of passengers per one flight. Comparing the years 2010 and 2017, this number increased by as much as 32 people, which should also be considered as a derivative of the increase in the size of the aircraft.

Taking the number of passengers and operations performed in individual ports into consideration, the strong leader in the Polish aviation market in the analyzed period is Warsaw Chopin Airport (Fig. 3a, 3b and Fig. 4a, 4b). In 2017, almost 16 million passengers were served in this port and almost 160,000 operations were carried out. The next places in this list included airports in Kraków (5.8 million passengers and 44.2 thousand operations), Gdańsk (4.6 million and 36.5 thousand) and in Katowice (3.9 million and 27.3 thousand). 


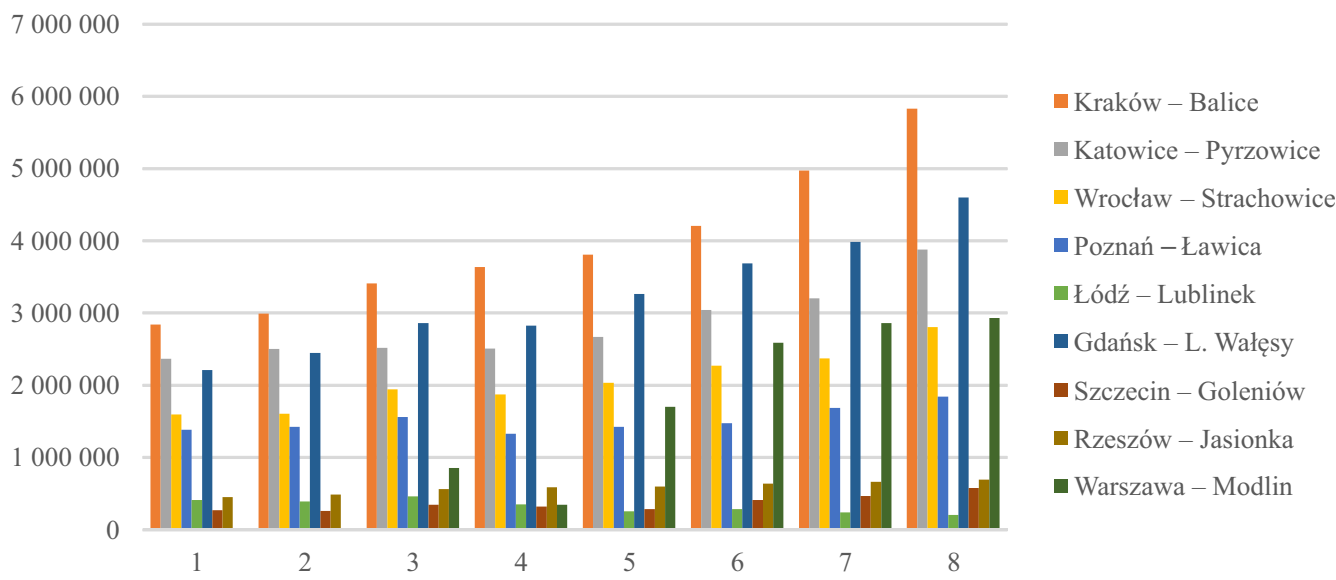

Fig. 3a. The number of passengers served by Polish airports in 2010-2017 (excluding the Warsaw-Chopin airport) Source: own study based on (ULC 2018)

Rys. 3a. Liczba pasażerów obsłużonych przez polskie porty lotnicze w latach 2010-2017 (z wyłączeniem lotniska Warszawa-Chopin)

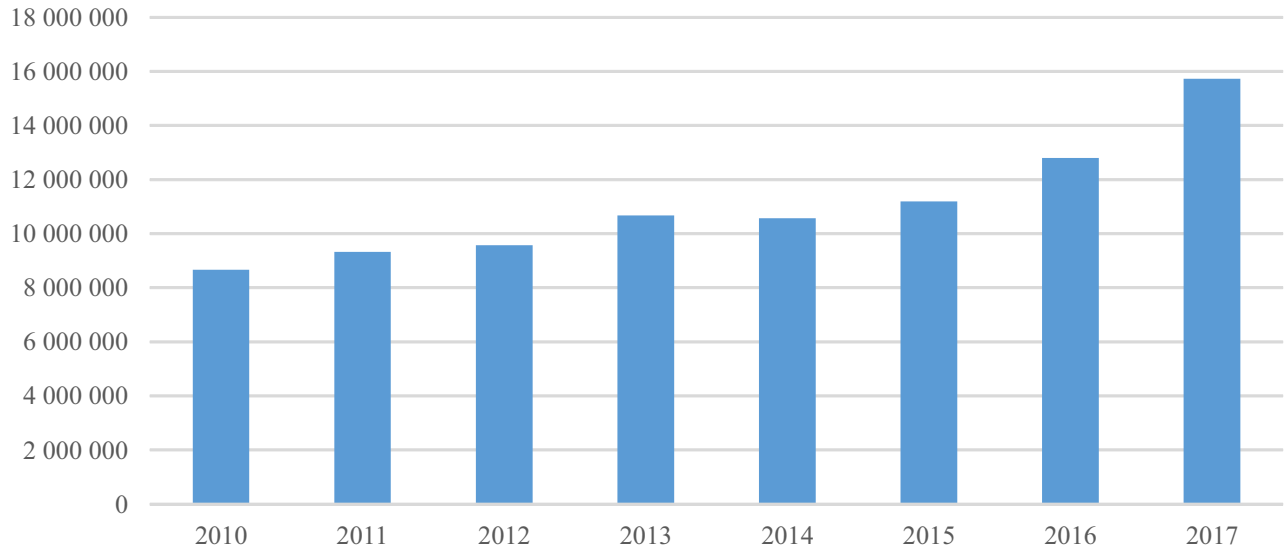

Fig. 3b. The number of passengers served at the Warsaw-Chopin airport in 2010-2017 Source: own study based on (ULC 2018)

Rys. 3b. Liczba pasażerów obsłużonych na lotnisku Warszawa-Chopin w latach 2010-2017

Looking at the dynamics of changes in aviation rates in 2010-2017, the upward trend in each period was maintained at two airports: Kraków-Balice and Rzeszów-Jasionka. In Kraków, however, the increments were much higher and often exceeded $10 \%$ year-on-year (the highest in 2016-2017, when they amounted to 17-18\%). For Rzeszów, the increase in passenger numbers was most visible in 2012 (over 15\% year-on-year), while in the remaining years it fluctuated between $2-8 \%$. However, the largest overall increase in the analyzed period 
was recorded by Szczecin and Gdańsk airports. In the first case, the increase in the number of passengers served in 2017 compared to 2010 was $115 \%$, and for the second $108 \%$. For comparison, in the same period the Warsaw airport recorded an 82\% increase, in Kraków 105\%, and in Rzeszów 53\%.

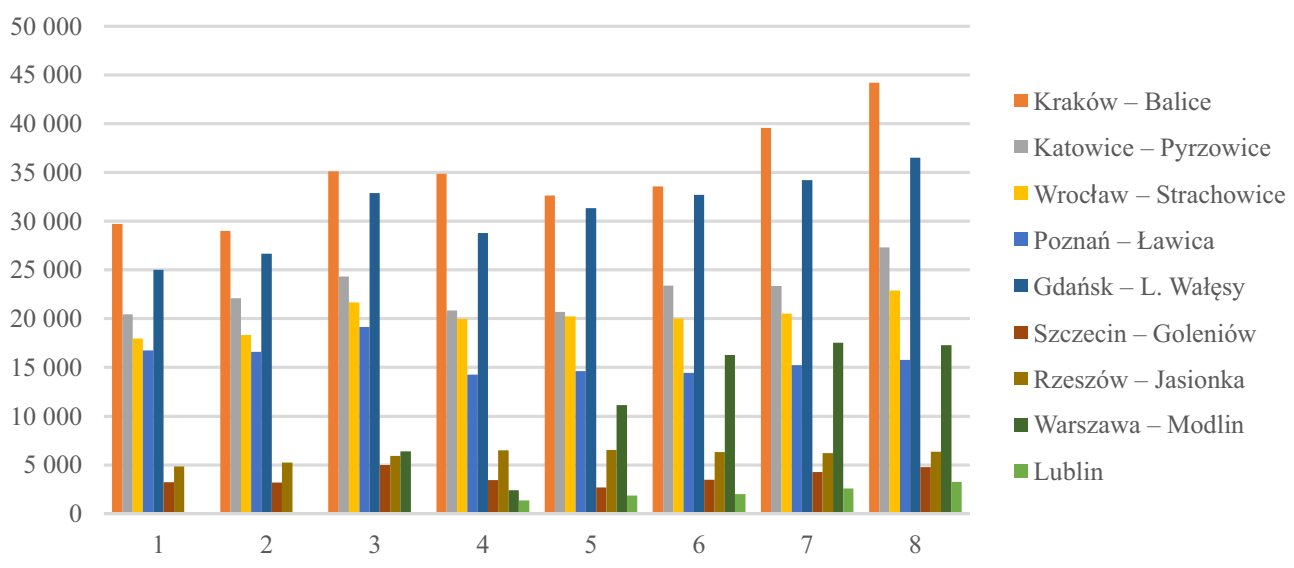

Fig. 4a. Number of passenger operations performed at Polish airports in 2010-2017

(excluding the Warsaw-Chopin airport)

Source: own study based on (ULC 2018)

Rys. 4a. Liczba operacji pasażerskich wykonanych na polskich portach lotniczych w latach 2010-2017 (z wyłączeniem lotniska Warszawa-Chopin)

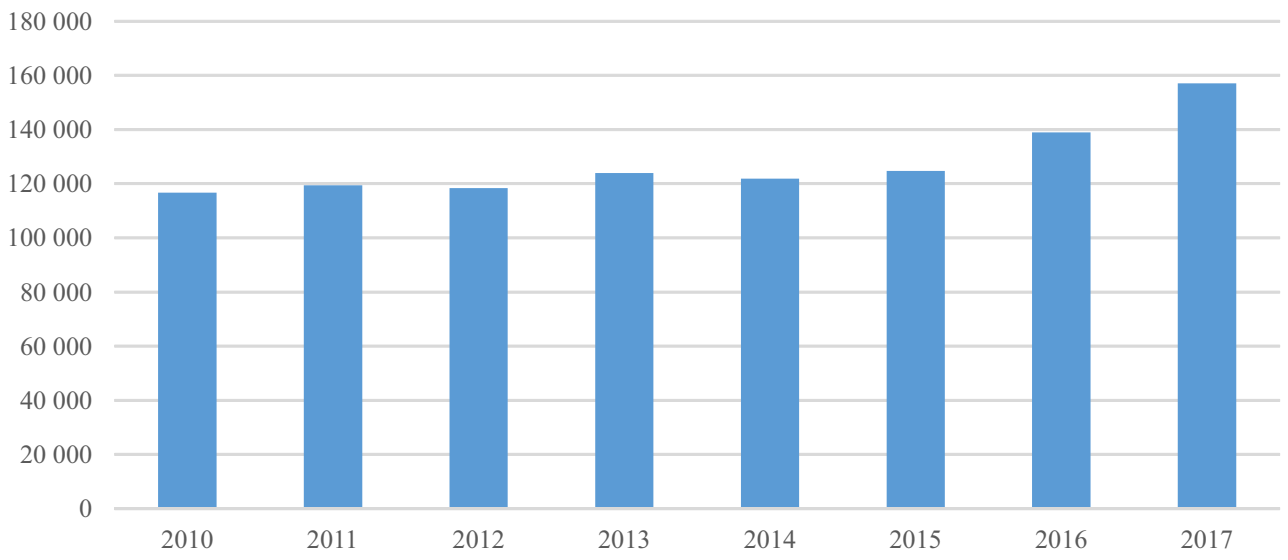

Fig. 4b. Number of passenger operations performed at the Warsaw-Chopin airport in 2010-2017 Source: own study based on (ULC 2018)

Rys. 4b. Liczba operacji pasażerskich wykonanych na lotnisku Warszawa-Chopin w latach 2010-2017 
The change in the number of passenger operations at individual airports was slightly less dynamic (see Figure 4a, 4b), although it also showed an upward trend. This was primarily due to the fact that the increase in the number of passengers was driven not only by a larger number of available flights, but also by such factors as: increasing the capacity of planes and increasing the fill rate for seats.

The total number of aviation operations carried out at Polish airports at the end of 2017 amounted to approximately 341.2 thousand and it was over 100 thousand greater than in 2010 . During this period, the highest growth rate was demonstrated by airports in Kraków (48.75\%), Szczecin (47.79\%), Gdańsk (45.98\%), Warsaw (34.58\%) and Katowice (33.5\%). The declines were noted by airports in Poznań $(-5.77 \%)$ and Łódź $(-46.71 \%)$.

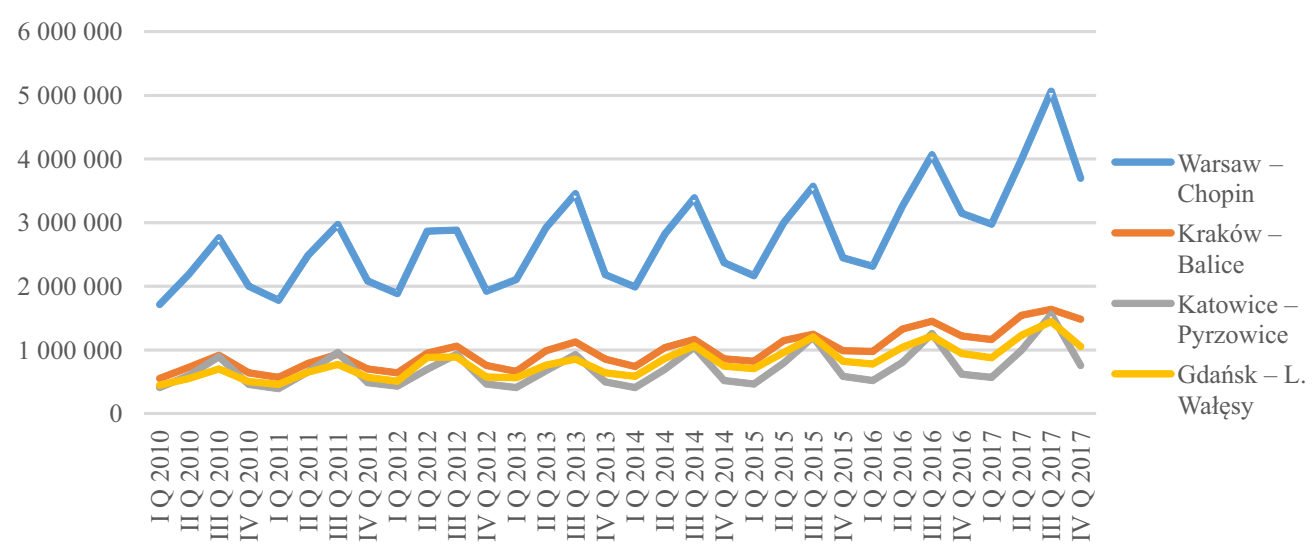

Fig. 5. The number of passengers served by the four largest Polish airports in 2010-2017 (quarterly) Source: own study based on (ULC 2018)

Rys. 5. Liczba pasażerów obsłużonych przez cztery największe polskie porty lotnicze w latach 2010-2017 (w ujęciu kwartalnym)

The phenomenon that accompanies changes in passenger traffic at Polish airports is its seasonality. This is clearly shown by the data presented in Figure 5. There are passenger numbers on a quarterly basis for the four largest Polish airports. Increased passenger traffic can be observed in the third quarter of the year (July-September), which seems understandable due to the fact that it is a period in which many people opt for vacation. In the third quarter of 2017, approximately 12.8 million passengers were served at all Polish airports. For comparison, in the first quarter it was 7.5 million, in the second it was 10.3 million, and in the fourth quarter it was 9.3 million people. However, looking at the percentage increase in passenger numbers in 2010-2017, the largest changes were recorded in the second and fourth quarters (about a two-fold increase compared to the base year). This is probably due to the fact that Poles are more and more willing to take vacation in months other than July or August. Another reason probably is that people are travelling more often for purposes other than leisure. 


\section{Comparison of Jet fuel prices and dynamics of changes in passenger traffic in Poland}

From the perspective of the Polish aviation sector, Jet fuel (also sometimes called Jet 1) should be considered the most important fuel. They are used in jet airplanes with turbine engines, and therefore it is crucial for the development of the entire market and above all, tourism. This part of the study will present an analysis of the price formation of the fuel in 2011-2017 (no uniform data from 2010, hence the decision to omit it in the analysis). Jet fuel quotes from PKN Orlen website, which prepares weekly collations in relation to Polish airports were used for this purpose (PKN Orlen 2018). The prices presented in further comparisons are arithmetic averages for individual quarters of the year, in Polish zlotys (PLN) per one liter of fuel.

Figure 6 shows how the prices of Jet fuel in 2011-2017 were shaped for transports carried out at the Warsaw Chopin Airport. Table 3 is a summary of selected statistical data of this fuel. In each of these sets it can be seen that the analyzed period was characterized by an advantage of the downward trend in Jet fuel prices. These prices reached the highest level in the first quarter of 2012, when they exceeded PLN 3.50/1. The next two quarters were characterized by relatively low fluctuations in the quotations of this fuel, which was reflected in the low level of coefficient of variation for the whole of 2012 (1.53\%). In the period from the third quarter of 2012 to the first quarter of 2016 a clear price reduction was visible, which translated into a nearly two-fold drop in the value of this fuel (from almost PLN 3.50/1 to PLN 1.80/1). The declines were particularly intense from the second half of 2014 to the beginning of 2016 and resulted mainly from a significant reduction in oil prices - a raw material from which aviation

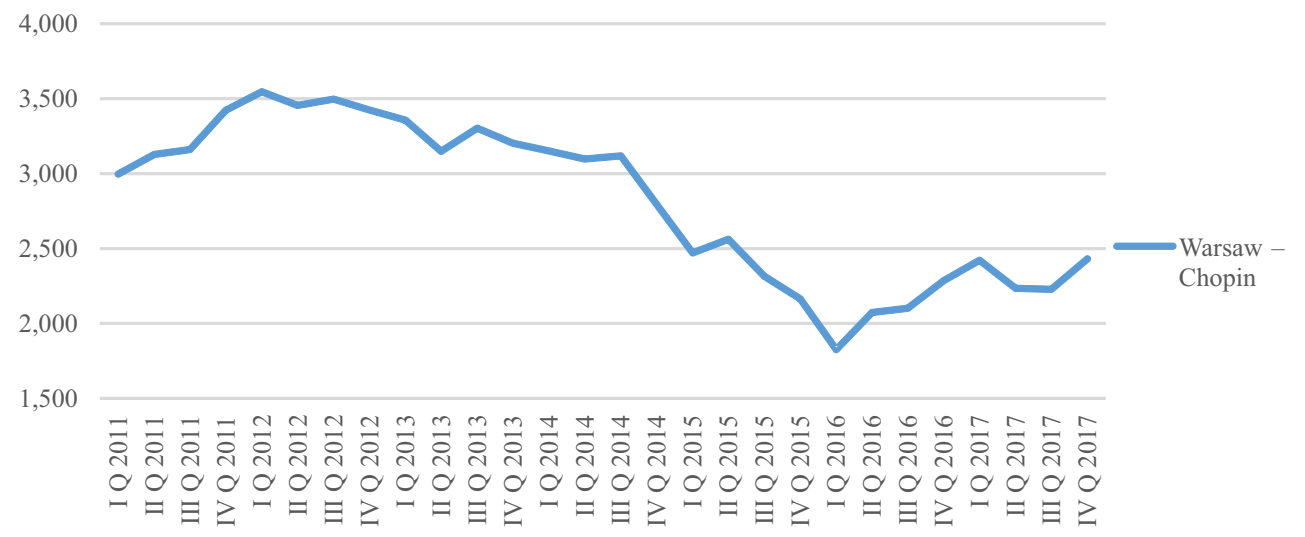

Fig. 6. Average Jet fuel prices (in PLN per 1 liter) at the Warsaw Chopin Airport in the following quarters from 2011-2017

Source: own study based on (PKN Orlen 2018)

Rys. 6. Ceny paliwa Jet (w zł za 1 litr) na lotnisku im. F. Chopina w Warszawie w kolejnych kwartach z lat 2011-2017 
fuels are processed. The years 2016-2017 are a clear dominance of the upward trend, also related to the increase in oil prices.

TABLE 3. Selected statistical data for Jet prices* (in PLN per 1 liter) at the Warsaw Chopin Airport in 2011-2017

TABELA 3. Wybrane dane statystyczne dla cen paliwa Jet (w zł za 1 litr) na lotnisku im. F. Chopina w Warszawie w latach 2011-2017

\begin{tabular}{|c|c|c|c|c|c|}
\hline \multirow{2}{*}{ Year } & \multicolumn{5}{|c|}{ Selected statistical data } \\
\cline { 2 - 6 } & average & standard deviation & $\begin{array}{c}\text { coefficient of } \\
\text { variation }\end{array}$ & minimum & maximum \\
\hline 2011 & 3,128 & 0,179 & $5,71 \%$ & 2,998 & 3,423 \\
\hline 2012 & 3,457 & 0,053 & $1,53 \%$ & 3,426 & 3,548 \\
\hline 2013 & 3,149 & 0,094 & $2,98 \%$ & 3,149 & 3,357 \\
\hline 2014 & 3,097 & 0,165 & $5,33 \%$ & 2,795 & 3,151 \\
\hline 2015 & 2,562 & 0,175 & $6,83 \%$ & 2,165 & 2,562 \\
\hline 2016 & 2,074 & 0,189 & $9,13 \%$ & 1,826 & 2,286 \\
\hline 2017 & 2,235 & 0,113 & $5,06 \%$ & 2,227 & 2,431 \\
\hline
\end{tabular}

* Calculated statistics refer to weekly prices from particular years.

Source: own study.

Analyzing the prices of Jet fuel, It is worth paying attention to the different level of fluctuations in these prices in the analyzed period. To investigate this phenomenon, two statistical quantities were used, illustrating the distribution of variable values of a given distribution (in this case, prices): standard deviation and coefficient of variation. It is undoubtedly draws attention the quite high value of the coefficient of variation in 2014-2016, which was mainly caused by intense downward movements in these prices. During this period, after a temporary stagnation and even a decrease in the number of passengers and passenger operations carried out by Polish airports in 2012-2013, a clear acceleration of the sector's development can be seen. Thus, it seems that the low level of fuel prices in recent years has been one of the factors that encouraged the more frequent use of Polish airports.

To verify the validity of the hypothesis put forward, Pearson's linear correlation coefficient was calculated for the number of passengers using the four largest Polish airports (Warsaw, Kraków, Katowice, Gdańsk) and the level of Jet fuel prices in 2011-2017 at these airports. The results of these analyzes are presented in the form of Table 4. The calculated values of the Pearson coefficient refer to both the entire period (the last column) and individual quarters. The division into quarters was applied due to the seasonal intensification (third quarter of the year) and the weakening (first and fourth quarter) of passenger traffic.

Looking at the values of the calculated correlation coefficients, it should be stated that there is a strong negative relationship between Jet fuel prices and the number of people deciding to travel 
TABLE 4. The value of Pearson linear correlation coefficient for Jet fuel prices and the number of passengers served at selected Polish airports in 2011-2017 (quarterly and annual)

TABELA 4. Wartość współczynnika korelacji liniowej Pearsona dla cen paliwa Jet i liczby pasażerów obsłużonych w wybranych polskich portach lotniczych w latach 2011-2017

(w ujęciu kwartalnym i rocznym)

\begin{tabular}{|l|c|c|c|c|c|}
\hline \multicolumn{1}{|c|}{ Airport } & $1^{\text {st }}$ quarter & $2^{\text {nd }}$ quarter & $3^{\text {rd }}$ quarter & $4^{\text {th }}$ quarter & $\begin{array}{c}\text { The entire } \\
\text { period }\end{array}$ \\
\hline Warsaw Chopin Airport & -0.57 & -0.73 & -0.78 & -0.72 & -0.76 \\
\hline Kraków Airport & -0.76 & -0.86 & -0.83 & -0.75 & -0.83 \\
\hline Katowice Airport & -0.78 & -0.81 & -0.87 & -0.75 & -0.83 \\
\hline Gdańsk Lech Wałęsa Airport & -0.78 & -0.77 & -0.87 & -0.87 & -0.86 \\
\hline
\end{tabular}

Source: own study.

by air in a given period. The absolute value of this coefficient reached the highest values for the Gdańsk airport, slightly lower for Kraków and Katowice, and the lowest for Warsaw.

A particularly strong negative relationship was recorded in the third and fourth quarters of the year. It is worth emphasizing however, that the correlation between the number of passengers and the prices of Jet fuel was quite weakened in 2017, when both these figures grew. Taking only the years 2011-2016 into account, the correlation coefficient reached for this period values from -0.88 (Warsaw) to even -0.98 (Katowice). It seems, therefore, that passenger traffic reacts positively to price drops, undoubtedly contributing to the development of the aviation sector. Fuel prices, however, are not the only factor determining the progress in the Polish aviation sector, which is confirmed by the year 2017, in which - despite the increase in Jet fuel prices - the interest in travel resulted in increased passenger traffic.

\section{Conclusions}

The review of the situation on the Polish aviation market, made by the authors of the article showed that there are several leading companies in its subjective structure being producers, suppliers and ground handling agents of the discussed fuel category. These include PKN Orlen together with PETROLOT, operating in the Orlen Group and LOTOS - Air BP Polska as a joint venture of the LOTOS Group.

Analyses carried out in the further part of the article showed that in recent years passenger traffic in Poland has been developing quite intensively. This trend also concerns the global market, driven by Asian markets, whose share in the increase in the number of aviation transactions will continue to grow in the coming years. As air traffic is served by civil aircraft, the changes taking place on the aviation fuel market are also very important. The article takes pas- 
senger transport of people using national and international transport in 2010-2017 in Poland into account. The research also paid particular attention to the correlation between changes in the intensity of passenger traffic and the prices of one of the most important aviation fuels, which is undoubtedly Jet fuel. The work omitted other types of aviation gasoline, because of the significantly lower impact of their prices on the market and changes in the volume of passenger traffic. Passenger airplanes in civil aviation usually have turbojet engines in which Jet fuels are used.

The calculated values of Pearson's linear correlation coefficient showed that in the analyzed period there was a strong negative relationship between the number of people using Polish airlines and the price of Jet fuel. This dependence was most intense usually in the third quarters of the year, when passenger traffic was the largest. It also drew attention to the fact that the correlation between these values in the last analyzed year (2017) decreased, when both Jet fuel prices increased and the number of passengers using Polish airlines continued to increase. This phenomenon shows that fuel prices are an important factor influencing development in the Polish aviation sector, but not decisive. It is also worth noting that the increase in Jet fuel prices may manifest itself in limiting passenger traffic with a certain delay, which in turn may pose a significant risk to enterprises whose financial result is strongly dependent on the number of aviation transactions. Therefore, it seems that these enterprises should undertake actions allowing for protection against the risk related to fluctuations in fuel prices. The tools to counteract this type of market risk will be one of the future directions of research by the authors of the article.

The publication was financed from the funds of the Faculty of Management AGH University of Science and Technology in Krakow, intended for statutory research.

\section{References}

BERNACIAK, P. 2017. Demand for aviation fuels (Popyt na paliwa lotnicze). [Online] http://logistyka.wnp. pl/popyt-na-paliwa-lotnicze,297592_2_0_0.html [Accessed: 2018-05-24] (in Polish).

GUS 2018. Passenger transport by air (Przewozy pasażerów transportem lotniczym). [Online] https://stat. gov.pl/metainformacje/slownik-pojec/pojecia-stosowane-w-statystyce-publicznej/705,pojecie.html [Accessed: 2018-05-27] (in Polish).

IATA 2015. IATA Guidance Material for Sustainable Aviation Fuel Management, $2^{\text {nd }}$ Edition. [Online] http://www.iata.org/whatwedo/environment/Documents/IATA\%20Guidance\%20Material\%20for\%20 SAF.pdf [Accessed: 2018-05-20].

PĄGOWSKI, Z. 2009. Air fuels and oils (Lotnicze paliwa i oleje). Prace Instytutu Lotnictwa Nr 199, p. 119. [Online] http://ilot.edu.pl/wp-content/uploads/2011/03/PIL_199.pdf [Accessed: 2018-05-20] (in Polish).

PKN Orlen 2018. Price of JET A1Fuel Archive (Cena paliwa JET A-1 Archiwum). [Online] https://www. orlen.pl/PL/DlaBiznesu/Paliwa-lotnicze/Strony/Cena-paliwa-JET-A-1-Archiwum.aspx [Access: 201803-22] (in Polish).

Annual reports of The Polish Oil Industry and Trade Organisation - Polska Organizacja Przemysłu i Handlu Naftowego (POPiHN) [Online] http://www.popihn.pl/raporty2.php [Accessed: 2019-02-26] (in Polish and English). 
Rynek Lotniczy 2018. ACI World: Dynamic development of the aviation market in the world (ACI World: Dynamiczny rozwój rynku lotniczego na świecie). [Online] http://www.rynek-lotniczy.pl/wiadomosci/ aci-world-dynamiczny-rozwoj-rynku-lotniczego-na-swiecie-3419.html [Accessed: 2018-05-22].

SIPIŃSKI, D. 2014. Report: The plane is full, what about the profit? (Raport: Samolot peten, co z zyskiem?) [Online] http://www.pasazer.com/news/12623/raport,samolot,pelen,co,z,zyskiem.html [Access: 201805-22] (in Polish).

ULC 2013. Analysis of Passenger Transport in Polish Airports in 2013 (Analiza Przewozów Pasazerskich w Polskich Portach Lotniczych w 2013 roku). [Online] http://ulc.gov.pl/_download/statystyki /2014/1q_2014/Analiza_2013.pdf [Access: 2018-05-25] (in Polish).

ULC 2018. Analysis of the aviation market (Analiza rynku lotniczego). [Online] http://ulc.gov.pl/pl/regulacja-rynku/397-statystyki-i-analizy-rynku-transportu-lotniczego/3734-analizy-rynku-lotniczego [Accessed: 2018-05-25] (in Polish).

WALKÓW, M. 2018. PKN Orlen strengthens its position at the Czech airport. It provides fuel for aircraft (PKN Orlen umacnia pozycję na czeskim lotnisku. Dostarcza paliwo do samolotów). [Online] https:// businessinsider.com.pl/finanse/handel/pkn-orlen-udzial-w-rynku-paliwa-lotniczego-w-czechach/ qqwxh94 [Accessed: 2018-02-20] (in Polish).

\section{Rozwój rynku paliw lotniczych w Polsce a zmiany w cywilnym ruchu pasażerskim}

\section{Streszczenie}

Rozwój transportu lotniczego oddziałuje na poszczególne elementy rynku paliw lotniczych. W ostatnich latach obserwuje się wzrost zarówno liczby pasażerów, jak i liczby operacji pasażerskich. Zjawisko to dotyczy także pasażerów i liczby operacji obsługiwanych przez polskie porty lotnicze, co przekłada się na coraz większe zużycie paliw w Polsce.

Autorzy opracowania podjęli próbę przybliżenia charakterystyki paliw lotniczych wykorzystywanych w różnego rodzaju statkach powietrznych. Do najważniejszych z nich, z perspektywy polskiego sektora lotniczego, należy zaliczyć przede wszystkim paliwo Jet. Wspomniane paliwo odgrywa kluczową rolę w lotnictwie cywilnym.

W artykule dokonano ponadto przeglądu podmiotów działających w badanym sektorze. Część empiryczną pracy poświęcono $\mathrm{z}$ kolei analizie zmian w lotniczym transporcie pasażerskim w Polsce oraz zmianom cen paliwa typu Jet na polskim rynku paliw. Z przeprowadzonych badan wynika, że dynamika zmian liczby pasażerów, a także liczby operacji pasażerskich na polskich lotniskach charakteryzowały się wzrostowym trendem, a sam przyrost liczby pasażerów napędzany był nie tylko przez większą liczbę dostępnych lotów, ale także takimi czynnikami, jak: zwiększenie pojemności samolotów i wzrost współczynnika wypełnienia miejsc. 
Autorzy podjęli również próbę zbadania siły zależności pomiędzy liczbą pasażerów decydujących się skorzystać z polskich portów lotniczych a cenami paliwa Jet, które w ostatnich latach ulegały dość znacznym wahaniom. W tym celu wykorzystano wartość współczynnika korelacji liniowej Pearsona, a analizowany okres objął lata 2011-2017. Wykorzystane w opracowaniu dane dotyczące ruchu pasażerskiego, pochodziły przede wszystkim z okresowych raportów, przygotowywanych przez Urząd Lotnictwa Cywilnego (ULC).

SŁOWA KLUCZOWE: rynek paliw lotniczych, ceny paliw lotniczych, cywilny transport pasażerski 